\title{
Vertical gastrectomy in overweight and non-overweight rats ${ }^{1}$
}

\author{
Fernando Issamu Tabushi', Melissa Spena Stueber ${ }^{\mathrm{II}}$, Benur Polonio ${ }^{\mathrm{III}}$, João Carlos Domingues Repka ${ }^{\mathrm{IV}}$, Sérgio Ossamu Ioshii ${ }^{\mathrm{V}}$, \\ Paulo Afonso Nunes Nassif ${ }^{\mathrm{vI}}$
}

DOI: http://dx.doi.org/10.1590/S0102-865020160100000008

IPhD, Associate Professor, Postgraduate Program in Principles of Surgery, Faculdade Evangélica do Paraná (FEPAR), Curitiba-PR, Brazil. Intellectual and scientific content of the study; technical procedures; acquisition, analysis and interpretation of data; manuscript writing.

IIFellow Master degree, Postgraduate Program in Surgical Clinic, Universidade Federal do Paraná (UFPR), Curitiba-PR, Brazil. Technical procedures. IIIPhD, Associate Professor, Department of Surgical Technique and Experimental Surgery, UFPR, Curitiba-PR, Brazil. Scientific and intellectual content of the study, conception and design of the study, manuscript preparation, critical revision.

${ }^{\text {IV }} \mathrm{PhD}$, Clinics Hospital, UFPR, Curitiba-PR, Brazil. Scientific and intellectual content of the study; conception and design of the study; acquisition, analysis and interpretation of data; technical procedures.

${ }^{\text {v } P h D, ~ D e p a r t m e n t ~ o f ~ M e d i c a l ~ P a t h o l o g y, ~ U F P R, ~ C u r i r t i b a-P R, ~ B r a z i l . ~ H i s t o p a t h o l o g i c a l ~ e x a m i n a t i o n s . ~}$

${ }^{\mathrm{V}} \mathrm{PhD}$, Associate Professor, Postgraduate Program in Principles of surgery, FEPAR, Curitiba-PR, Brazil. Conception and design of the study, manuscript writing, critical revision, final approval.

\begin{abstract}
PURPOSE: To compare the two lines suture (total and seromuscular) after partial gastrectomy in normal and overweight rats.

METHODS: Forty Wistar rats were distributed in two groups. Group A received normal diet; group B, normal diet and supplementation with saccharose in the water. When group B progressed to a statistically greater weight than the animals of group A, the experiment (sleeve-like gastrectomy) was conducted with gastrorraphy in two sutures lines (total and seromuscular). The animals were distributed into two subgroups of 10 . A1 and A2 subgroups were sacrificed at 7 and 14 days postoperatively as well as B1 and B2. Mortality, morbidity, complications attributed to the gastric suture, biochemical dosages, Lee index, macroscopy, weight of retroperitoneal and gonadal fat, optical microscopy with hematoxylin-eosin and picrosirius-red, were the evaluation parameters.

RESULTS: The overweight group achieved statistically greater weight after 16 weeks in induced obesity; there was no mortality or complications with clinical consequences attributable to morbidity. The overweight group had statistically greater weight of gonadal and retroperitoneal fat. The difference was observed in urea, albumin, total cholesterol and indirect bilirubin.

CONCLUSION: There was no outcome difference between the overweight and non-overweight group in two suture lines in gastrorrhaphy after sleeve-like gastrectomy.
\end{abstract}

Key words: Stomach. Sutures. Anastomosis, Surgical. Rats. 


\section{Introduction}

Obesity reaches alarming levels in Western society. The medical literature has shown that overweight people have higher surgical complications, among them dehiscence, digestive fistulas and higher incidence of abdominal incisional hernias ${ }^{1,2}$.

Bariatric surgery is well established as a durable option to reduce and maintain the loss of weight excess in patients submitted to $\mathrm{it}^{3-5}$. Most techniques include sutures and/or gastrointestinal anastomoses performed manually or with mechanical staplers ${ }^{6-10}$

The manual suture can be made in one $e^{11-13}$ or two suture lines $^{14}$, with good results. Gastrointestinal anastomoses had a long evolution during the history of medicine ${ }^{15,16}$. The manual suture of the edges of intestinal wounds usually caused by trauma, was probably one of the first attempts to make the synthesis of these intestinal lesions ${ }^{15,17-19}$.

Even today, gastrointestinal anastomoses are still object of study, and when carried out in overweight can have complications in higher levels, especially those related to dehiscence ${ }^{2,20}$.

The goal of this study was to compare the healing process and complications of suture lines in overweight and nonoverweight animals after sleeve-like gastrectomy.

\section{Methods}

Forty EPM-1 Wistar rats, males, with average weight of $180 \mathrm{~g}$ were distributed in two groups of 20, being group A with normal weight and B overweight. The animals in both groups received regular diet for the species. The $\mathrm{B}$ group received sucrose supplementation $(300 \mathrm{~g} / \mathrm{L})$ rather than water. They were all weighed weekly.

After 16 weeks B group reached statistically higher weight than group A. At this time was initiated the experiment consisting of general anesthesia with isoflurane $(3 \mathrm{ml})$, xylazine $(10 \mathrm{mg} / \mathrm{kg})$ and ketamine $(100 \mathrm{mg} / \mathrm{kg})$. Antibiotic prophylaxis was performed with ceftriaxone $(50 \mathrm{mg} / \mathrm{kg})$. After being anesthetized, the naso-anal length of the rat was measured in centimeters and the correlation weight/length gave the body mass index, the Lee index, which is the ratio of the cube root of body weight (in grams) of the naso-anal length (in centimeters) multiplied by one thousand (Figure 1).

$$
\text { INDICE DE LEE }=\frac{\sqrt[3]{\text { peso }}}{C N A} \times 1000
$$

FIGURE 1 - Lee index formula.
The surgical procedure was median laparotomy (Figure $2 \mathrm{~A}$ ), vertical gastrectomy (Figure $2 \mathrm{~B}$ and $2 \mathrm{C}$ ) and gastrorrhaphy in two suture lines with 6-0 polypropylene, one full invaginating continuous suture and the second seromuscular with separated stitches (Figure 2D).

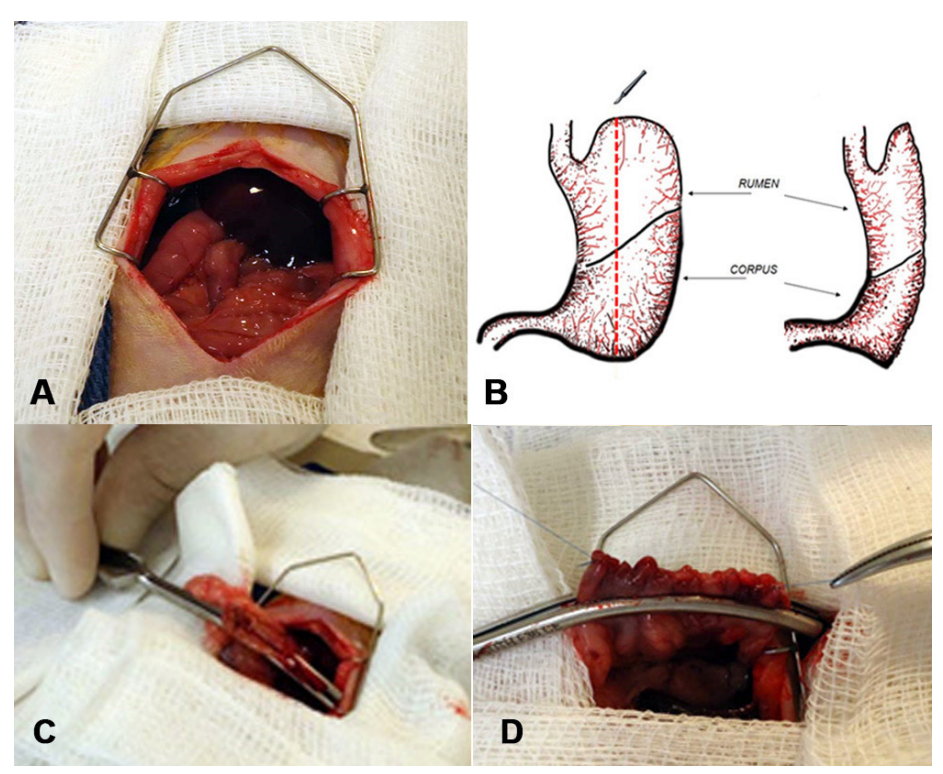

FIGURE 2 - Surgical procedure: A) Median laparotomy; B) Schematic drawing of the sleeve-like gastrectomy; C) Vertical gastrectomy; D) Gastrorraphy.

The musculoaponeurotic layer was closed with continuous suture using polydioxanone 3-0 and the skin with polyamide 4-0 in separate stitches.

The animals received water (group A) or sucrose solution (group B) once recovered from anesthesia and normal diet for the species after 12 hours for both; then they were divided into two subgroups of 10 to be euthanized on 7 and 14 days of the postoperative period. The same anesthetic technique was used with intracardiac puncture for blood collection for biochemical analysis until death

Postoperative analysis of kidney function, lipid profile, blood glucose and insulin were asked. The preoperative clinical analysis parameters were those described in the literature as normal for mice. The operative evolution and surgical complications of all animals were recorded as well.

Necropsy evaluated presence of adhesions and fistula. The stomach with gastrorrhaphy was removed for optical microscopy with $\mathrm{H} \& \mathrm{E}$ and picrosirius-red collagen dosage of the corpus as well of the rumen (Figure 3A). After removal of the stomach, extraction of retroperitoneal (Figure $3 \mathrm{~B}$ ) and gonadal fat (Figure 3C) for weighing was realized. 


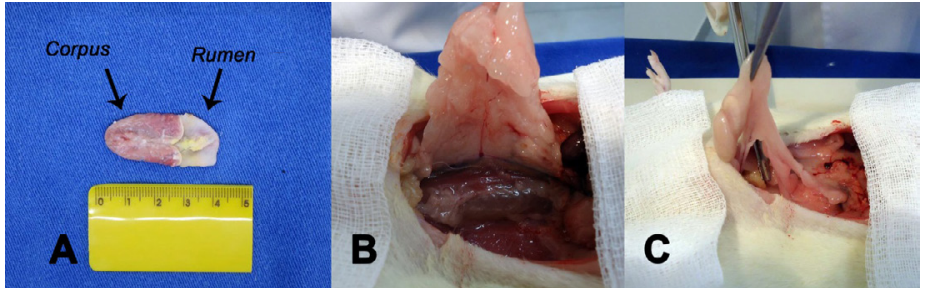

FIGURE 3- Stomach was removed with the scar: A) Identification of the corpus and rumen in the scar; B) Removal of the retroperitoneal fat; $\mathbf{C}$ ) Removal of gonadal fat.

\section{Statistical analysis}

The statistical analysis were considered quantitative variables were described as mean, median, minimum, maximum and standard deviation and qualitative variables as frequencies and percentages. To compare the weights evaluated in three stages (initial weight, weight at surgery and weight sacrifice), it was considered the model of analysis of variance with repeated measures. Multiple comparisons were made using the LSD test (least significant difference). To compare two groups regarding the quantitative variables was considered the Student $t$ test for independent samples or assessed by the Kolmogorov-Smirnov test. To evaluate the association between two dichotomous qualitative variables was used Fisher's exact test.

P0.05 values indicated statistical significance. Data were analyzed with the software Statistica v.8.0.

\section{Results}

The overweight group evolved after 16 weeks for an average weight of $519.83 \pm 67.66$, statistically higher than the non-overweight group (average weight of $402.41 \pm 46.51$ ).

Most of the animals showed loose adhesions to neighboring structures. One rat had a small subcutaneous seroma. Two rats (one from Group A and one from group B) showed fistulas of the gastric suture blocked by the adjacent organs, but without changing the clinical behavior or feeding. These complications were not identified during the autopsy.

Regarding the Lee index there was no statistical difference when compared non-overweight with overweight group

When comparing the weight of gonadal and retroperitoneal fat of the overweight and non-overweight group, it was noted that the overweight showed statistically greater weight in both gonadal and retroperitoneal fat when compared to nonoverweight group.

In hematological study of leukocytes, platelets, biochemical analysis of glucose, evidence of hepatic and renal function, and insulin, changes were observed only in urea which was statistically lower in the overweight group on the $7^{\text {th }}$ postoperative and lower in the non-overweight group on the $14^{\text {th }}$ day when compared to the normal standard for mices. The indirect bilirubin was statistically lower in the overweight group on the $14^{\text {th }}$ day. Albumin was higher in the overweight group on the $7^{\text {th }}$ day and total cholesterol higher in $7^{\text {th }}$ and $14^{\text {th }}$ days in overweight group (Table 1).

TABLE 1 - Comparison of the variables urea, indirect bilirubin, albumin and cholesterol between overweight and nonoverweight groups at 7 and 14 days after surgery.

\begin{tabular}{|c|c|c|c|c|c|c|c|c|c|}
\hline & Variable & Group & $\mathrm{N}$ & Mean & Median & Minimum & Maximum & Standard deviation & $\mathrm{p}$ value \\
\hline \multirow{8}{*}{$\begin{array}{l}0 \\
\text { م. } \\
r\end{array}$} & \multirow{2}{*}{ Urea } & Non-overweight & 10 & 53,10 & 49,50 & 25,00 & 104,00 & 20,89 & \\
\hline & & Overweight & 10 & 37,20 & 37,00 & 27,00 & 50,00 & 7,04 & $\mathbf{0 , 0 4 3 ^ { a }}$ \\
\hline & \multirow{2}{*}{ Bilirubin } & Non-overweight & 10 & 0,09 & 0,10 & 0,02 & 0,22 & 0,06 & \\
\hline & & Overweight & 10 & 0,11 & 0,09 & 0,00 & 0,31 & 0,09 & $0,553^{\mathrm{a}}$ \\
\hline & \multirow{2}{*}{ Albumin } & Non-overweight & 10 & 0,82 & 0,80 & 0,60 & 1,10 & 0,14 & \\
\hline & & Overweight & 10 & 1,09 & 1,20 & 0,70 & 1,30 & 0,21 & 0,004 \\
\hline & \multirow{2}{*}{ Cholesterol } & Non-overweight & 10 & 72,30 & 71,00 & 64,00 & 79,00 & 5,54 & \\
\hline & & Overweight & 10 & 81,50 & 80,00 & 67,00 & 97,00 & 7,78 & $\mathbf{0 , 0 0 7}$ \\
\hline \multirow{8}{*}{$\begin{array}{l}\dot{0} \\
\text { ¿ } \\
\Xi\end{array}$} & \multirow[t]{2}{*}{ Urea } & Non-overweight & 10 & 55,10 & 53,00 & 44,00 & 71,00 & 8,97 & \\
\hline & & Overweight & 10 & 38,00 & 39,00 & 23,00 & 57,00 & 10,66 & $\mathbf{0 , 0 0 1}{ }^{\mathrm{a}}$ \\
\hline & \multirow[t]{2}{*}{ Bilirubin } & Non-overweight & 10 & 0,09 & 0,10 & 0,00 & 0,16 & 0,06 & \\
\hline & & Overweight & 10 & 0,04 & 0,03 & 0,01 & 0,09 & 0,03 & $0,034^{a}$ \\
\hline & \multirow[t]{2}{*}{ Albumin } & Non-overweight & 10 & 0,84 & 0,85 & 0,10 & 1,30 & 0,44 & \\
\hline & & Overweight & 10 & 0,87 & 0,90 & 0,80 & 0,90 & 0,05 & $0,971^{b}$ \\
\hline & \multirow[t]{2}{*}{ Cholesterol } & Non-overweight & 10 & 84,20 & 84,00 & 69,00 & 105,00 & 11,60 & \\
\hline & & Overweight & 10 & 71,20 & 70,00 & 49,00 & 90,00 & 12,17 & 0,025 \\
\hline
\end{tabular}

P.O.: Post operative; ${ }^{a}$ Student's $t$ test for independent samples, $p<0,05 ;{ }^{b}$ Nonparametric Mann-Whitney, $p<0,05$. 
The analysis of optical microscopy with H\&E staining showed no statistical difference in re-epithelialization of the mucosa, coaptation of layers (serous and muscle, mucosa and submucosa) and inflammation of the serous and muscular layers, mucosa and submucosa between non-overweight and overweight subgroups at 7 and 14 days, both rumen and corpus. Good cicatrization was observed in most animals; they had reepithelialization of the mucosa, mucosa/submucosa and serous/ muscle coaptation, consistent with inflammatory process in respective days.

It was found statistical difference in the inflammatory parameters when comparing subgroups within the two groups. Those on the $7^{\text {th }}$ day, both in the non-overweight and overweight group, had higher amount of acute inflammatory process in relation to the subgroups on the $14_{\text {th }}$ day after surgery. These results were expected, since the animals in 14 days would be in later healing time compared to the $7^{\text {th }}$ day.

There was no statistical difference when analyzing the amount of collagen type I and type III in non-overweight and overweight groups at 7 and 14 days.

Laboratorial tests of the rats in the pre surgery were not conducted because the necessary amount of blood for analysis of all the variables is obtained by intracardiac puncturing, making it impossible to continue the study.

\section{Discussion}

All animals evolved satisfactorily during the study. Due the fact that rat is animal with resistance to infection, the use of prophylactic antibiotics and antiseptic techniques may have contributed to the good results. These aspects were also observed by other researchers ${ }^{21,22}$.

In the Lee index analysis there was no statistical difference when comparing the non-overweight with overweight group. Although it has been observed that the overweight group had statistically greater weight than the non-overweight, this finding was not corroborated by the results of Lee index ${ }^{23}$. This may be due to several reasons: the period after the operation was short (14 days), or as Stephens ${ }^{24}$ observed in another paper, the correlation length with the weight was not adequate for measuring body mass index.

The vertical gastrectomy afforded weight reduction at the time of euthanasia in both groups. This reduction, after obesity induction in rats, was also observed by other authors with other techniques ${ }^{22,25}$.

Most of the animals showed loose adhesions to neighboring structures. One had a small subcutaneous seroma and two fistulas of the gastric suture blocked by the adjacent organs.
When comparing the weights of gonadal and retroperitoneal fat between the overweight and non-overweight group, it was found that fat had statistical greater weight both gonadal and retroperitoneal compared to the non-overweight group. This fact can contribute to validate the obesity induction model with sucrose used in this study. It was found that in the $14^{\text {th }}$ day the animals exhibited weight reduction of these fats in relation to the $7^{\text {th }}$ day.

Total cholesterol in the overweight group was statistically higher than the values of the non-overweight both on $7^{\text {th }}$ and $14^{\text {th }}$ day. It is believed that there was insufficient time for reduction with sleeve-like gastrectomy surgery. If the animals had had longer postoperative period, 60 or 90 days, the values could be minor, as Bonhomme ${ }^{22}$ verified. Suzuki ${ }^{21}$ found decreased triglyceride levels after gastric bypass, but without statistical significance.

After analyzing the optical microscopy with H\&E no statistical difference was observed when studying the pathological parameters. It was observed in most animals good cicatrization, with re-epithelialization of the mucous layer and coaptation of mucosa/submucosa and serous/muscle, consistent with inflammatory process in days $7^{\text {th }}$ and $14^{\text {th }}$ days. It was found statistical differences in the inflammatory process comparing the subgroups within groups. On the $7^{\text {th }}$ day both groups had greater acute inflammatory process in relation to the subgroups in the $14^{\text {th }}$ day. These results are as expected, since the animals in day 14 were in later period of cicatrization compared to the $7^{\text {th }}$. Other authors found similar results, as Santos ${ }^{25}$ after studying gastrorrhaphy with gastric suture with polypropylene in rats sacrificed on days 3 and 7; it was observed in optical microscopy of the animals that most had good coaptation of the edges and discrete acute or moderate reaction. The same was observed by Tabushi ${ }^{11}$ in healing of rat's cecum.

There was no statistical difference when analyzing the amount of collagen type I and type III in non-overweight and overweight groups, in both periods. However, it was found that the amount of type I was higher in the non-overweight compared to the overweight, and the amount of type III was higher in the overweight compared to non-overweight group. Given that type I is associated with more mature and well structured wound and type III with initial healing, the tendency of the overweight group, having more collagen type III and less type I, was to have slower cicatrisation, like the results found by Xing et al. ${ }^{11}$, who demonstrated that after the obesity induction in rats, the abdominal cicatrization is delayed in overweight compared to non-overweight.

In this study it was found an albumin dosage statistically higher in the overweight group at 7 P.O. contradicting the results of the literature ${ }^{26}$. Although not being the objective of this paper, it was not possible to understand why the albumin increased in the overweight group in the 7 P.O. Due the existence of few 
studies dosing serum albumin in rats submitted to gastrectomy in the literature, there is a need to continue this research looking for better explanation for this point.

\section{Conclusion}

The healing process in the vertical gastrectomy with two suture lines showed no difference when non-overweight rats were compared with the overweight, although some biochemical variables showed some differences between groups.

\section{References}

01. Diener MK, Voss S, Jensen K, Büchler MW, Seiler CM. Elective midline laparotomy closure: the INLINE systematic review and meta-analysis. Ann Surg. 2010 May;251(5):843-56. doi: 10.1097/ SLA.0b013e3181d973e4.

02. Xing L, Culbertson EJ, Wen Y, Robson MC, Franz MG. Impaired laparotomy wound healing in obese rats. Obes Surg. 2011 Dec;21(12):1937-46. doi: 10.1007/s11695-011-0377-2.

03. Capella JF, Capella RF. The weight reduction operation of choice: vertical banded gastroplasty or gastric bypass? Am J Surg. 1996 Jan;171(1):74-9. Am J Surg. 1996 Jan;171(1):74-9. PMID: 8554155.

04. Sjöström L, Narbro K, Sjöström CD, Karason K, Larsson B, Wedel $\mathrm{H}$, Lystig T, Sullivan M, Bouchard C, Carlsson B, Bengtsson C, Dahlgren S, Gummesson A, Jacobson P, Karlsson J, Lindroos AK, Lönroth H, Näslund I, Olbers T, Stenlöf K, Torgerson J, Agren G, Carlsson LM; Swedish Obese Subjects Study. Effects of bariatric surgery on mortality in Swedish obese subjects. N Engl J Med. 2007 Aug 23;357(8):741-52. PMID: 17715408.

05. Branco-Filho AJ, Nassif LS, Menacho AM, Aurichio RAE, Siqueira DED, Fernandez RM. Treatment of morbid obesity with vertical gastrectomy. Arq Bras Cir Dig. 2011 Mar; 24(1):52-4. doi: 10.1590/ S0102-67202011000100011.

06. Androsov PI. Experience in the application of the instrumental mechanical suture in surgery of the stomach and rectum. Acta Chir Scand. 1970;136(1):57-63. PMID: 4932400.

07. Quilici FA, Cordeiro F, Faria Junior PC, Reis Neto JA. Mechanical and manual anastomoses of the extraperitoneal rectum: experimental comparative study in dogs. Arq Bras Cir Dig. 1990;5(2):41-50.

08. Lustosa SA, Matos D, Atallah AN, Castro AA. Stapled versus handsewn methods for colorectal anastomosis surgery: a systematic review of randomized controlled trials. São Paulo Med J/Rev Paul Med. 2002;120(5):132-6.

09. Nassif PA, Valadão JA, Malafaia O, Torres OJ, Garcia RF, Klostemann FC. Technical modification for sleeve gastrectomy. Arq Bras Cir Dig. 2013;26 Suppl 1:74-8. PMID: 24463904.

10. Ramos AC, Bastos EL, Ramos MG, Bertin NT, Galvão TD, de Lucena RT, Campos JM. Technical aspects of laparoscopic sleeve gastrectomy. Arq Bras Cir Dig. 2015;28 Suppl 1:65-8. doi: 10.1590/ S0102-6720201500S100018.

11. Polonio B, Hirt ALA, Repka JCD, Souza VCT. Estudo comparative entre as anastomoses colorretais em plano único extramucoso e com anel biofragmentável no reto extraperitoneal de cães. Acta Cir Bras. 1994;9(3):118-23.

12. Polonio B, Repka JCD, Grinaldi DM, Novo NF, Juliano Y, Nigro AJT. Anastomoses esôfago-esofágicas cervicais término-terminais por invaginação e com anel biofragmentável: estudo experimental em cães. Acta Cir Bras. 1996;11(2):51-7, 1996.

13. Tabushi FI, Nomura LM, Malafaia O, Ribas-Filho JM, Polonio B, Repka JCD, Ioshii SO, Costa-Filho OAA. Cecorraphy in single layer using polypropylene and poliglecaprone 25 threads. Comparative study in rats. Acta Cir Bras. 2012;27(3):251-5. PMID: 22460256.

14. Shikata S, Yamagishi H, Taji Y, Shimada T, Noguchi Y. Singleversus two- layer intestinal anastomosis: a meta-analysis of randomized controlled trials. BMC Surg. 2006 Jan 27;6:2. PMID: 16438733.

15. Kerr HH. The development of intestinal surgery. J Am Med Assoc. 1923;81(8):641-7. doi: 10.1001/jama.1923.02650080023008.

16. Senn, N. Enterorrhaphy: its history, technique and present status. J Am Med Assoc. 1893;21:215-35.

17. Ballantyne GH. Intestinal suturing. Review of the experimental foundations for traditional doctrines. Dis Colon Rectum. 1983 Dec;26(12):836-43. PMID: 6357675.

18. Hardy KJ. A view of the development of intestinal suture. Part I. From legend to practice. Aust N Z J Surg. 1990 Apr;60(4):299-304. PMID: 2181994.

19. Hardy KJ. A view of the development of intestinal suture. Part II. Principles and techniques. Aust N Z J Surg. 1990 May;60(5):37784. PMID: 2185733.

20. Baracs J, Huszár O, Sajjadi SG, Horváth OP. Surgical site infections after abdominal closure in colorectal surgery using triclosancoated absorbable suture (PDS Plus) vs. uncoated sutures (PDS II): a randomized multicenter study. Surg Infect (Larchmt). 2011 Dec;12(6):483-9. doi: 10.1089/sur.2011.001.

21. Suzuki S, Ramos EJ, Goncalves CG, Chen C, Meguid MM. Changes in GI hormones and their effect on gastric emptying and transit times after Roux-en-Y gastric bypass in rat model. Surgery. 2005 Aug;138(2):283-90. PMID: 16153438.

22. Bonhomme S, Guijarro A, Keslacy S, Goncalves CG, Suzuki S, Chen C, Meguid MM. Gastric bypass up-regulates insulin signaling pathway. Nutrition. 2011 Jan;27(1):73-80. doi: 10.1016/j. nut.2010.08.005.

23. Malafaia AB, Nassif PA, Ribas CA, Ariede BL, Sue KN, Cruz MA. Obesity induction with high fat sucrose in rats. Arq Bras Cir Dig. 2013;26 Suppl 1:17-21. PMID: 24463893.

24. de Bona Castelan J, Bettiol J, d'Acampora AJ, Castelan JV, de Souza JC, Bressiani V, Giroldi SB. Sleeve gastrectomy model in Wistar rats. Obes Surg. 2007 Jul;17(7):957-61. PMID: 17894157.

25. dos Santos OJ, de Carvalho FF Jr, Sauaia-Filho EN, Santos RH, Santos RA, Barbalho WG. Gastric healing process with raw extract of Euphorbia tirucalli L.: study in rats. Arq Bras Cir Dig. 2013 NovDec;26(4):256-9. PMID: 2451003.

26. Aires Neto T, Cavalcante JF, Brandão-Neto J, Almeida $\mathrm{Md}$, de Rezende AA, Egito ES, de Azevedo IM, Pinheiro LA, Medeiros VB, Medeiros Ada C. Total gastrectomy with substitution of stomach by jejunal pouch with and without duodenal passage. Study in rats. Acta Cir Bras. 2005;20 Suppl 1:167-72. PMID: 16186984.

\section{Correspondence:}

Dr. Fernando Issamu Tabushi Avenida Três Marias, 1175/casa 41 82310-000 Curitiba - PR Brasil

Received: Jun 14, 2016

Review: Aug 15, 2016

Accepted: Sep 16, 2016

Conflict of interest: none

Financial source: none

${ }^{1}$ Research performed at Postgraduate Program in Principles of Surgery, Medical Research Institute, Faculdade Evangélica do Paraná (FEPAR), Curitiba-PR, Brazil. 